\title{
RELATO DE CASO
}

\section{CRUSTED SCABIES IN A CHID WITH SYSTEMIC LUPUS ERYTHEMATOSUS}

\author{
Nurimar C.F. Wanke, Claudia Melo and Viviam Balassiano
}

\begin{abstract}
A child with systemic lupus erythematosus who has been treated with prednisone for three years, developed crusted scabies. Scrapings from lesions revealed Sarcoptes scabiei adult mites mad eggs. The patient died with septicemia and renal failure soon after starting topical $20 \%$ sulfur. A marked improvement was observed in the cutaneous lesions.
\end{abstract}

Key-words: Scabies. Crusted scabies. Norwegian scabies.

Crusted scabies is a rare, severe, highly contagious variant of classical scabies; the lesions consist of generalized scaling and hyperkeratotic, crusted plaques affecting the skin of the whole body. The infestation by the mite Sarcoptes scabiei var hominis is massive and predisposition to this form occurs in association with mentally retarded ${ }^{78}$ and physically debilitated patients. Recent reports have increasingly linked scabies with immunesuppression ${ }^{12345610}$. It is essencial for clinicians to be familiar with this form of scabies because of its highly contagious nature and unusual clinical signs, which may be easily overlooked. To our knowledge this article presents the first report of a child with systemic lupus erythematosus who subsequently developed crusted scabies.

\section{REPORT OF A CASE}

An 11-year-old while girl was initially seen in April 1988 with an erythematous purpuric papular eruption on the lower extremities. Medical history did not disclose weight loss, pain in multiple joints, hair loss or increasing sensivity to sunlight. The remainder of the physical examination was unremarkable.

The hemogram showed a leukopenia count of $5600 / \mathrm{cu} \mathrm{mm}$, a hemoglobin level of $8.5 \mathrm{~g} / \mathrm{dl}$ and a ESR of $95 \mathrm{~mm} /$ hour. A direct Coomb's test was

\footnotetext{
Department of Internal Medicine, School of Medicine and Dermatology Unit, Clementino Fraga Filho University Hospital, Federal University of Rio de Janeiro, Rio de Janeiro, RJ, Brasil.

Address to: Dra. Nurimar C.F. Wanke. Hospital Universitário Clementino Fraga Filho. Av. Brigadeiro Trompowsky, $\mathbf{s} / \mathbf{n}$, Cidade Universitária, 21910-000 Rio de Janeiro, RJ, Brasil. Reçebido para publicação em 17/12/91.
}

weakly positive and the antinuclear antibody (ANA) test was positive in a titer of $1: 320$, in a homogeneous pattern. The $\mathrm{C} 3$ component was below normal limits at $30.3 \mathrm{mg} / \mathrm{dl}$ (Normal $50-120 \mathrm{mg} / \mathrm{dl}$ ) and C4 also, at 15 (Normal, $20-50 \mathrm{mg} / \mathrm{dl}$ ). Urinalysis disclosed an abnoraml sedimant and $10 \mathrm{mg} / 100 \mathrm{ml}$ of protein excretion.

The normal - appearing skin was examined by direct immunofluorescence and revealed subepidermal deposition of IgG, IgM, IgA, C3 and fibrin.

Anedle biopsy specimen of the kidney disclosed diffuse glomerulopathy type IV (WHO) associated to systemic lupus erythematosus. Direct immunofluorescence microscopy revealed the deposition of IgG, IgM, C3 in granular mesangial, loop deposits and fibrinogen.

Oral prednisone therapy was started, $2 \mathrm{mg} / \mathrm{kg}$ daily; over the next three years the patient had several episodes of both clinical and laboratory evidences of relapses.

In February 1991 the patient was admitted because of the progressive nephropathy so that perotoneal dialysis was started. A demartologic consultation was requested to evaluate a diffuse and pruritic eruption. There were gray hyperkeratotic plaques covering the skin of the scalp, face, ear lobes, trunk, buttocks and dorsum of the fingers; crusted papules on the dorsum of the hands and extremities; no erythema or dystrophic nails but subungual debris; palms and soles were spared (Figure 1). The patient's mother and the health care workers from the pediatric uint were infected. Skin scrapings from affected areas showed eggs and live scabies mites. Treatment with $20 \%$ sulfur added to shake lotion applied once a day all over the body was startes. Her condition deteriorated and on the eighth 
Relato de Caso. Wanke NCF, Melo C, Balassiano V. Crusted scabies in a child with systemic lupus erythematosus. Revista da Sociedade Brasileira de Medicina Tropical 25:73-75, jan-mar, 1992.

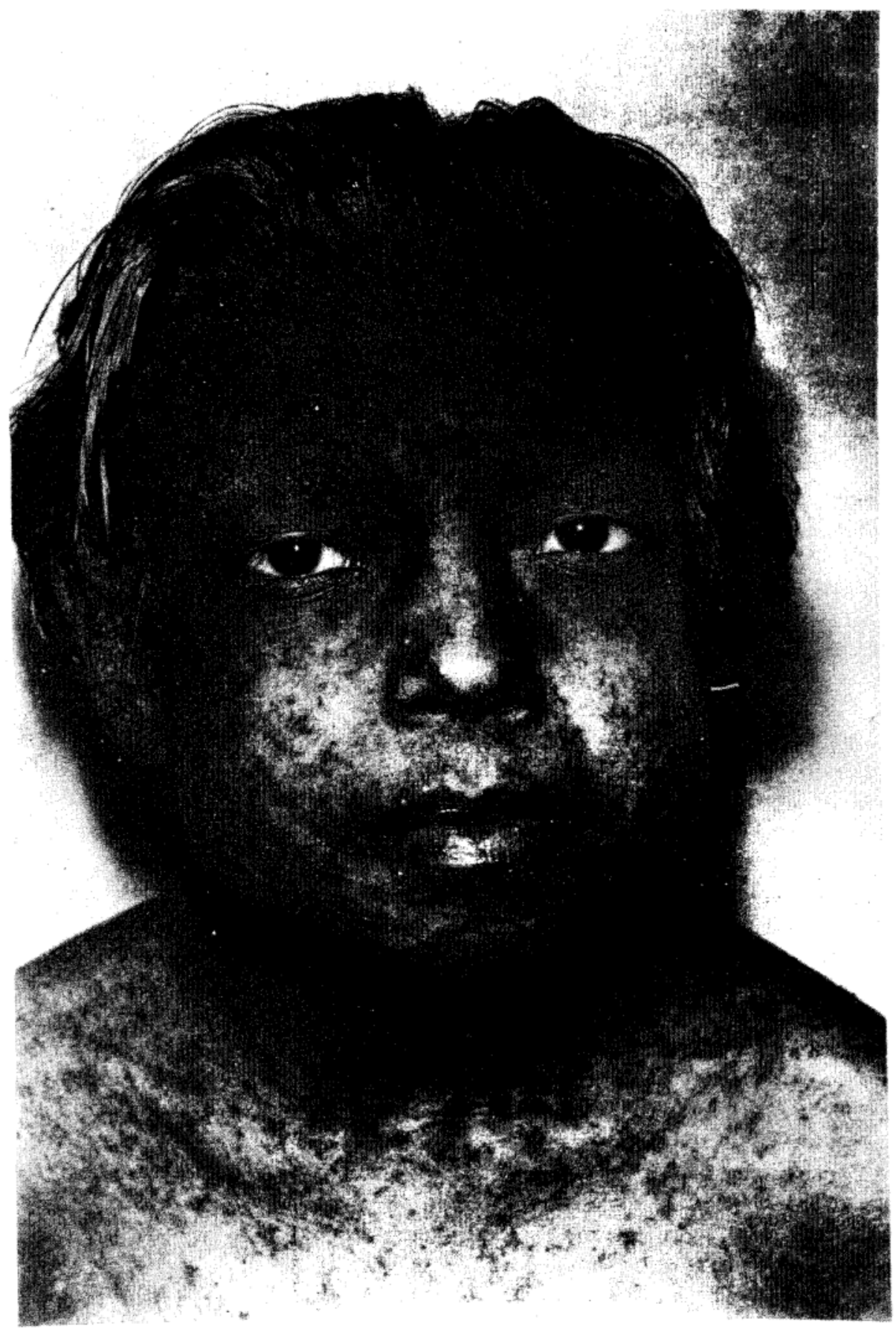

Figure 1 - Hyperkeratotic plaques on the face, scalp and trunk.

day she died with Pseudomonas aeruginosa septicemia and renal failure. A marked improvement was observed in the patient's cutaneous manifestations.

\section{DISCUSSION}

The diagnosis of systemic lupus erythematous was based upon the following criteria: anemia, 
Relato de Caso. Wanke NCF, Melo C, Balassiano V. Crusted scabies in a child with systemic lupus erythematosus. Revista da Sociedade Brasileira de Medicina Tropical 25:73-75, jan-mar, 1992.

leukopenia, abnormal ANA in a titer of 1:320, increasing proteinuria, a renal biopsy specimen demonstrating immune complex nephritis, immunofluorescent deposits of immunoglobulin and complement at the dermoepidermal junction of normal appearing skin.

Prior to hospital admission there were signs of scabies that is a mild pruritic papular eruption on the trunk and extremities that evolved into the crusted form. The underlying lupus erythematosus and the long course of prednisone probably contributed to this evolution. Crusted scabies has followed immunosupressive therapy ${ }^{2710}$. The role of immune mechanisms in limiting the number of scabies mites is not well defined. Extreme proliferation might result from primary failfure of the cell-mediated immune response or a secondary induction of immune tolerance ${ }^{2}$.

One may suppose that the severity of the infestation could be related to the patient's low living conditions; however, in other patients with crusted scabies, personal hygiene has not been found to significanfly alter the rate of mite proliferation ${ }^{2}$.
In spite of the impaired host defense mechanisms our patient responded to sulphur therapy. The lesions possibly provided a portal of entry for the infection.

On the eight day of topical therapy the child died with septicemia and renal failure. We believe that there is not any association between these two facts. However one patient reported in the literature died shortly after commencement of therapy with $20 \%$ precipitaded sulfur ointment ${ }^{9}$.

\section{RESUMO}

É descrito um caso de sarna crostosa em criança portadora de lupus eritematoso sistêmico em tratamento com prednisona há três anos. O raspado das lesões cutâneas revelou ovos e ácaros adultos de Sarcoptes scabiei. A paciente faleceu por sepsis e insuficiência renal pouco tempo após inicio da terapêutica tópica com enxofre a $20 \%$. Melhora importante foi observada no quadro dermatológico.

Palavras-chaves: Escabiose. Sarnacrostosa. Sarna norueguesa.

\section{REFERENCES}

1. Barnes L, Mc Callister RE, Lucky AW. Crusted (Norwegian) scabies. Occurence in a child undergoing a bone marrow transplant. Archives of Dermatology 123:95-97, 1987.

2. Glover A, Young L, Goltz AW. Norwegian scabies in acquired immunodeficiency syndrome: report of a case resulting in death from associated sepsis. Journal of the American Academy of Dermatology 16:396-399, 1987.

3. Hall JC, Brewer JH, Appl BA. Norwegian scabies in a patient with acquired immunodeficiency syndrome. Cutis 43:325-329, 1989.

4. Jucowics P, Ramon ME, Don PC, Stoner RK, Bamji $M$. Norwegian scabies in an infant with acquired immunodeficiency syndrome. Archives of Dermatology 125:1670-1671, 1989.

5. Rau RC, Baird IM. Crusted scabies in a patient with acquired immunodeficiency syndrome. Journal of the American Academy of Dermatology 15:10581059, 1986.

6. Sadick N, Kaplan MH, Pahwa SG, Sarngadharan MG. Unusual features of scabies complicating human T-lymphocytic virus type III infection. Journal of the American Academy of Dermatology 15:482-486, 1986.

7. Savall R, Puig X, Felip A. Sarna noruega. Medicina Cutânea Ibero Latina Americana 13:115-117, 1985.

8. Scherbenske JM, Benson PM, Rotchford JP, James WD. Cutaneous and ocular manifestations of Down syndrome. Journal of the American Academy of Dermatology 22:933-938, 1990.

9. Wolf R. Krakowski A. Atypical crusted scabies. Journal of the American Academy of Dermatology 17:434-436, 1987.

10. Wolf R. Krakowski A. Scabies norvegica. Bericht über zwei Fälle. Hautarzt 38:430-431, 1987. 